\title{
Pembuatan Media Pembelajaran Berbasis Powerpoint dan Pemanfaatan Aplikasi Android untuk Guru Bahasa Arab
}

\author{
${ }^{1 *}$ Nurhidayati, ${ }^{2}$ Imam Asrori, ${ }^{3}$ Mohammad Ahsanuddin, ${ }^{4}$ M. Wahib Dariyadi \\ Universitas Negeri Malang; Jalan Semarang 5 Malang \\ *Corresponding author: nurhidayati.fs@um.ac.id
}

\begin{abstract}
Abstrak
Dari segi sarana dan prasarana, 109 MTs di Kabupaten Bojonegoro sudah memiliki sarana-prasarana yang memadai, di beberapa madrasah fasilitas Internet juga telah tersedia, namun dalam penggunaanya belum optimal. Para guru masih sangat jarang yang memanfaatkan komputer itu untuk tujuan peningkatan pembelajaran apalagi menggunakan media pembelajaran berbasis Powerpoint dengan berbagai aplikasinya ,pengabdian ini dilakukan untuk meningkatkan pengetahuan dan meningkatkan keterampilan guru-guru bahasa Arab MTs di Bojonegoro tentang konsep media pembelajaran berbasis powerpoint, materi yang dikembangkan adalah media pembelajaran bahasa Arab dan pembuatan video pembelajaran melalui android, metode yang digunakan adalah pelatihan dan pendampingan. Hasil pelatihan ini menunjukkan bahwa keterampilan para guru cukup meningkat dengan indikator bahwa produk luaran pelatihan telah memenuhi standar media yang menarik serta berpotensi dapat mempercepat pencapaian kompetensi siswa dalam pembelajaran bahasa arab.
\end{abstract}

Kata kunci-Media Pembelajaran, Pembelajaran inovatif, Bahasa Arab, Powerpoint

\section{Abstract}

In terms of facilities and infrastructure, 109 MTs in Bojonegoro already have adequate infrastructure, in some madrasah Internet facilities are also available, but the use is not optimal yet. Teachers are still very rarely using the computer for the purpose of improving learning especially using Powerpoint-based learning media with a variety of applications, this dedication is done to increase knowledge and improve the skills of Arabic MTs teachers in Bojonegoro about the concept of powerpoint-based learning media, the material developed is a medium for learning Arabic and making learning videos through Android, the method used is training and mentoring. The results of this training show that the skills of teachers have improved considerably with indicators that the training output products have met attractive media standards and can potentially accelerate the achievement of student competencies in learning Arabic.

Keywords - Learning Media, Innovative Learning, Arabic, Powerpoint

\section{PENDAHULUAN}

$\mathrm{M}$ utu pendidikan kualitas guru sangat tergantung kepada bagi peningkatan mutu pendidikan secara rasional, Sehingga diharapkan dengan adanya perubahan kemajuan zaman dalam bidang Iptek, akan menunjang juga kemajuan dan perubahan ke segi positif dalam pendidikan (Budiman, 2017; Killian, 2014). Di antara media hasil IPTEK adalah media power point, media powerpoint ini menarik untuk digunakan sebagai alat presentasi adalah berbagai kemampuan pengolahan teks, warna, dan gambar, serta animasi-animasi yang bisa diolah sendiri sesuai kreatifitas pengguna (Asrori \& Ahsanuddin, 2014). Hasil penelitian Srimaya (2017) menunjukan bahwa media pembelajaran powerpoint efektif untuk meningkatkan motivasi, keaktifan, dan hasil belajar. Melalui powerpoint pembelajaran bahasa Arab yang memuat banyak konsep yang abstrak dapat disajikan dengan lebih konkrit melalui visualisasi baik dalam bentuk gambar dua dimensi maupun tiga dimensi.

Dari segi sarana dan prasarana, 109 MTs di kabupaten Bojonegoro sudah memiliki saranaprasarana yang memadai, misalnya komputer dan LCD proyektor untuk sarana penunjang pembelajaran di kelas. Internet juga salah satu sarana yang 


\section{Nurhidayati dkk. / Jurnal Karinov Vol. 2 No. 3 (2019) 181-184}

disediakan beberapa madrasah. Namun demikian, dalam kenyataannya penggunaan sarana komputer itu masih belum optimal. Para guru masih sangat jarang yang memanfaatkan komputer itu untuk tujuan peningkatan pembelajaran apalagi menggunakan media pembelajaran berbasis Powerpoint dengan berbagai aplikasi tersebut (Gowaya dkk., 2019; Elpira \& Ghufron, 2015).

Tujuan kegiatan penerapan Ipteks ini adalah pertama untuk meningkatkan pengetahuan guru-guru bahasa Arab MTs tentang konsep media pembelajaran berbasis powerpoint, dan selanjutnya untuk meningkatkan keterampilan guru-guru bahasa Arab MTs dalam membuat media pembelajaran berbasis powerpoint. Media pembelajaran adalah segala piranti yang digunakan pengajar untuk memperbaiki proses pembelajaran, memperjelas keterangan pengajar mengenai makna atau pemikiran, melatih pebelajar untuk mencapai kemampuan tertentu dan memperoleh kebiasaan tertentu, menumbuhkan kecenderungan/orientasi dan menanamkan nilai (Achmad, 1983).

Berdasarkan penjelasan di atas, penggunaan media dalam pembelajaran, khususnya pembelajaran Bahasa asing, adalah sesuatu yang urgen dan merupakan bagian integral dari proses pembelajaran. Hasil penelitian Permatasari (2014) menyatakan terdapat pengaruh yang signifikan antara kemampuan menulis cerita pendek siswa sebelum menggunakan multimedia PowerPoint dengan kemampuan menulis cerita pendek setelah menggunakan multimedia PowerPoint. Begitu juga halnya dengan pembelajaran menulis bahasa Arab, maka sangat diperlukan kemampuan guru untuk mengembangkan media powerpoint tersebut (Putri, 2019; Primasari dkk., 2014).

Microsoft powerpoint merupakan aplikasi software yang dapat digunakan untuk menyampaikan materi berupa tulisan, gambar bentuk, foto, aneka warna dan jenis tulisan, fitur hyperlink, audio, video, dan animasi. Powerpoint merupakan media yang digunakan untuk menyampaikan poin-poin pokok dari materi yang kita sampaikan dengan fitur-fitur yang menarik. Berbagai fitur yang dapat digunakan pada media powerpoint menjadikan media ini mampu mengakomodir berbagai jenis gaya belajar siswa baik gaya belajar visual, audio, kinestetik, dan juga verbal. PowerPoint merupakan salah atau software milik Microsoft office (Ms.Office). Ms.Office memiliki sejumlah software, yaitu mencakup word processor (word 2002), Spreadsheet (Excel 2002), presentasi (powerpoint), E-mail, teleconferencing (Ner Meeting), dan DBMS (Acess 2002). Dalam sejarahnya Ms. Office berkembang mulai dari Ms. Office 2000, Ms. Office Xp. Ms. Ofice 2007, 2010, 2013 dan terakhir adalah 2019. Dengan perkembangan teknologi komputer ini, maka metoda pendidikan juga berkembang, sehingga proses pengajaran berbantuan komputer ini maju terus menuju kesempurnaannya, namun secara garis besarnya, dapat dikatergorikan menjadi dua, yaitu Computer-based training (CBT) dan Web-based training (WBT) (Saraswati \& Listiadi, 2019).

\section{METODE}

Secara umum proses pendekatan untuk membantu mitra dalam proses pelatihan pembuatan media pembelajaran berbasis powerpoint diperlihatkan pada gambar 1 berikut.

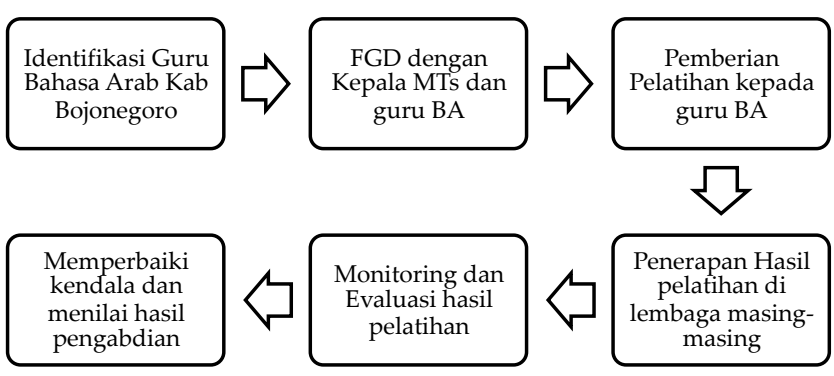

Gambar 1. Proses pelatihan pembuatan media pembelajaran

Untuk mengetahui keberhasilan kegiatan pelatihan ini dilakukan dua macam evaluasi, yaitu evaluasi program dan evaluasi hasil program. Evaluasi program dilakukan dengan menggunakan kuesioner untuk mendapatkan umpan balik dari peserta mengenai pelaksanaan program. Evaluasi hasil belajar dilakukan dengan memberikan tugas untuk membuat sendiri bahan ajar ajar berbasis powerpoint dan memantau serta membimbing pelaksanaan tugas-tugas administratif dan edukatif serta pembuatan karya-karya kreatif guru.

1. Ceramah tentang materi berikut. (1) Konsep, peran, dan jenis media pembelajaran berdasarkan kurikulum MTs 2013, (2) Media Powerpoint dan Pemanfatannya dalam proses pembelajaran Bahasa Arab di MTs, (3) Menjalankan program power point, memasukkan data, penataan layout, dan (4) Teknik memasukkan video pada media powerpoint, pembuatan video pembelajaran, dan pembuatan tautan dan editing video di android

2. Demonstrasi tentang langkah-langkah untuk penyusunan dan pengembangan media pembelajaran berbasis powerpoint. 


\section{Nurhidayati dkk. / Jurnal Karinov Vol. 2 No. 3 (2019) 181-184}

3. Latihan pembuatan media pembelajaran berbasis powerpoint.

4. Presentasi media powerpoint dan penerapanya dalam pembelajaran bahasa Arab.

5. Evaluasi hasil media pembelajaran yang telah disusun.

\section{HASIL DAN PEMBAHASAN}

Kegiatan pengabdian masyarakat yang dilaksanakan dengan acara tatap muka dan praktek pembuatan media pembelajaran bahasa arab berbasis powerpoint berjalan dengan baik dan lancar. Pertemuan tatap muka dengan metode ceramah dan demonstrasi, dilanjutkan latihan/praktek untuk membuat media pembelajaran, mulai dari ceramah tenang: (1) Konsep, peran, dan jenis media pembelajaran berdasarkan kurikulum MTs 2013, (2) Media Power point dan Pemanfatanya dalam proses pembelajaran Bahasa Arab di MTs, (3) Menjalankan program power point, memasukkan data, penataan layout, (4) Teknik memasukkan video pada media powerpoint, pembuatan video pembelajaran, dan pembuatan tautan dan editing video di android.

Waktu pelatihan yang cukup memberikan peluang kepada peserta untuk mempraktekkan materi yang sudah disampaikan pada hari pertama untuk dipraktikan sebagai latihan pada pertemuan hari kedua. Dari kegiatan latihan tampak bahwa guru memang sudah menguasai cara pembuatan media power point dan mempraktikkannya dalam pembelajaran bahasa Arab dengan baik, namun keberhasilan ini belum merata karena terdapat beberapa guru yang memang belum mampu mengopersionalkan laptop dengan baik.

Setiap pemberian sebuah tema kemudian dilanjutkan sesi tanya jawab. Berbagai pertanyaan diajukan secara antusias oleh para peserta dalam sesi tanya jawab. Secara garis besar inti dari pertanyaan para peserta adalah: pertama, langkah praktis penyusunan media powerpoint yang efektif dan menarik. Kedua, keungulan dan kelemahan media pembelajaran berbasis powerpoint. Ketiga, penggantian layout, font dan background dalam penyusunan media pembelajaran berbasis powerpoint, keempat, pembuatan link, kelima, pemberian efek suara dan animasi. Keenam, pembuatan video pembelajaran, dan terakhir adalah editing video di android. Program pengabdian pada masyarakat berupa pelatihan pengembangan media pembelajaran bahasa Arab berbasis power point dan pembuatan video pembelajaran melalui android yang sudah dilaksanakan ini menambah pengetahuan, keterampilan dan lebih percaya diri dalam menjalankan profesinya. Guru lebih semangat dan termotivasi untuk mengembangkan diri. Hasil pelatihan ini bermanfaat bagi sekolah, proses belajar mengajar bahasa Arab lebih menarik dengan digunakannya media pembelajaran yang lebih bervariasi. Disamping itu dengan adanya pelatihan pengembangan media pembelajaran ini menambah keterampilan guru dalam menyiapkan perangkat media pembelajaran sehingga mendukung kemampuan dan profesionalitas guru bahasa Arab MTs di Bojonegoro.

Hasil kegiatan pengabdian kepada masyarakat ini secara garis besar mencakup beberapa komponen sebagai berikut: 1 . Keberhasilan target jumlah peserta pelatihan 2. Ketercapaian tujuan pelatihan 3. Ketercapaian target materi yang telah direncanakan 4. Kemampuan peserta dalam penguasaan materi. Target peserta pelatihan seperti direncanakan sebelumnya adalah 50 guru bahasa Arab MTs baik negeri maupun swasta di Bojonegoro, namun dalam pelaksanaanya hanya 36 yang hadir. Beberapa guru tidak hadir karena ada tugas mendadak dari sekolah, ada juga yang berhalangan hadir karena sakit, dan keperluan keluarga yang tidak bisa ditinggalkan. Selain itu beberapa guru yang ditargetkan ikut tidak mau mendaftar karena mereka belum mengenal program komputer atau laptop. Dengan demikian dapat dikatakan bahwa target peserta tercapai 72 persen. Angka tersebut menunjukkan bahwa kegiatan dilihat dari jumlah peserta yang mengikuti dapat dikatakan cukup berhasil. Ketercapaian tujuan pelatihan pengembangan media pembelajaran secara umum sedah baik, namun keterbatasan waktu yang disediakan mengakibatkan tidak semua materi tentang pengembangan media pembelajaran dapat disampaikan secara detil. Namun dilihat dari hasil latihan para peserta yaitu kualitas media pembelajaran yang telah dihasilkan, maka dapat disimpulkan bahwa tujuan kegiatan ini dapat tercapai. Ketercapaian target materi pada kegiatan ini cukup baik, karena materi pelatihan telah dapat disampaikan secara keseluruhan.

\section{SIMPULAN}

Program pengabdian pada masyarakat berupa pelatihan pengembangan media pembelajaran bahasa Arab berbasis powerpoint dan pembuatan video pembelajaran melalui android. Hasil kegiatan ini meningkatkan semangat dan termotivasi guru untuk mengembangkan diri. Sebagai tambahan, program pelatihan ini menambah keterampilan guru dalam 
menyiapkan perangkat media pembelajaran sehingga mendukung kemampuan dan profesionalitas guru bahasa Arab MTs di Bojonegoro. Ketercapaian tujuan pelatihan pengembangan media pembelajaran secara umum sedah baik, namun keterbatasan waktu yang disediakan mengakibatkan tidak semua materi tentang pengembangan media pembelajaran dapat disampaikan secara detail.

\section{DAFTAR RUJUKAN}

Achmad, A.M.S. (1983). Sikulujiyat al-Wasail alTa'limiyyah wa Wasail Tadris al-Lughah alArabiyyah, Kairo: Dar al-Ma'arif.

Budiman, H. (2017). Peran teknologi informasi dan komunikasi dalam pendidikan. Al-Tadzkiyyah: Jurnal Pendidikan Islam, 8(1), 31-43.

Killian, N. (2014). Peran Teknologi Informasi Dalam Komunikasi Antar Budaya dan Agama. Jurnal Dakwah Tabligh, 15(2), 159-176.

Asrori, I., \& Ahsanuddin, M. (2015). Media Pembelajaan Bahasa Arab: dari Kartu Sederhana sampai Web Penjelajah Dunia. Malang: VC Bintang Sejahtera Press.

Permatasari, A.A. (2014). Pengaruh Penggunaan Multimedia Powerpoint Terhadap Peningkatan Kemampuan Menulis Cerita PendekPada Pembelajaran Bahasa Indonesia. PEDAGOGIA: Jurnal Ilmu Pendidikan, 12(1), 19-23.

Srimaya, S. (2017). Efektivitas Media Pembelajaran Power Point Untuk Meningkatkan Motivasi dan Hasil Belajar Biologi Siswa. Jurnal Biotek, 5(1), 53-68.

Saraswati, S., \& Listiadi, A. (2019). Pengembangan Bahan Ajar Computer Assisted Instruction (CAI) Menggunakan Adobe Captivate Pada Mata Pelajaran Komputer Akuntansi Untuk Kelas XI Akuntansi Smk Negeri 1 Surabaya. Jurnal Pendidikan Akuntansi (JPAK), 7(2), 254262.

Gowasa, S., Harahap, F., \& Suyanti, R. D. (2019). Perbedaan Penggunaan Media Powerpoint Dan Video Pembelajaran Terhadap Kemampuan Berpikir Tingkat Tinggi Dan Retensi Memori Siswa Pada Mata Pelajaran IPA di Kelas V SD. Jurnal Tematik, 9(1), 19-27.

Elpira, N., \& Ghufron, A. (2015). Pengaruh Penggunaan Media Powerpoint terhadap Minat dan Hasil Belajar IPA Siswa Kelas IV SD. Jurnal Inovasi Teknologi Pendidikan, 2(1), 94104.
Putri, V. R. (2019). Memaksimalkan Kompetensi Guru Melalui Fitur Kelas Maya Dalam Pembelajaran Bahasa Arab Sebagai Inovasi Pembelajaran Jaman Now. Proceeding Iain Batusangkar, 3(1), 323-332.

Primasari, R., Zulfiani, Z., \& Herlanti, Y. (2014). Penggunaan media pembelajaran di madrasah aliah negeri se-Jakarta Selatan. Edusains, 6(1), 67-72. 